Michą MęcZYŃSKI

Uniwersytet im. Adama Mickiewicza w Poznaniu, Polska

\title{
Rola menedżerów w zmianach organizacyjnych w firmach i instytucjach sektora kreatywnego poznańskiego regionu metropolitalnego
}

\author{
The Role of Managers in the Organisational Changes \\ of the Creative Sector Companies and Institutions \\ in the Poznań Metropolitan Region
}

\begin{abstract}
Streszczenie: Postępujące procesy globalizacji prowadzą do rosnącej konkurencji między firmami należącymi do różnych sektorów gospodarki. Zmieniające się wymagania rynku wymuszają na podmiotach gospodarczych wprowadzanie nowych strategii, które często zmieniają całkowicie ich struktury organizacyjne. Przewidziane w ramach tych strategii działania wiążą się z dużym ryzykiem, wynikającym z niepewnych rezultatów, wzrostu niezadowolenia wśród pracowników czy w wielu przypadkach redukcji zatrudnienia. Jednocześnie wprowadzane przekształcenia dotyczą m.in. wzrostu elastyczności firm i instytucji, także tych publicznych w zakresie świadczonych usług. Za wprowadzanie zmian w strukturach organizacyjnych przedsiębiorstw odpowiedzialni są kreatywni menedżerowie posiadający wysokie kwalifikacje. Cechy charakteru tych osób oraz niematerialny rodzaj wykonywanej przez nich pracy sprawiają, że uznawani są oni za przedstawicieli klasy kreatywnej (Florida, 2002). Powstające w wyniku ich decyzji nowe struktury organizacyjne w przedsiębiorstwach wiążą się m.in. z przekształcaniem układów hierarchicznych w struktury o charakterze sieciowym (Napier, Nilsson, 2006), zastępowaniem tradycyjnych działów firm przez tymczasowo działające grupy projektowe, skupiające specjalistów (Kloosterman, 2010; Landry, 2006). Te struktury zapewniają często nowe warunki pracy, sprzyjające rozwojowi kreatywności. Powstaje w ten sposób środowisko twórcze (Creative milieu) w firmie lub instytucji (Törnqvist, 2011).

Na podstawie przeprowadzonych wywiadów i ankiet w ramach realizacji dwóch międzynarodowych projektów badawczych (ACRE - Accommodating Creative Knowledge. Competitiveness of European Metropolitan Regions within the Enlarged Union i CREA.RE Creative Regions) autor określił rolę menedżerów w zmianach organizacyjnych w firmach i instytucjach sektora kreatywnego w poznańskim regionie metropolitalnym.
\end{abstract}

Abstract: The ongoing globalisation processes trigger ever-increasing competitiveness among companies of different sectors of the economy. The changing market requirements make companies introduce novel strategies, which often change completely their corporate structures. The activities envisaged by the strategies are subject to a high risk because of their uncertain effects. This may lead to an increased 
dissatisfaction among the workforce; their employees may be afraid of the new modes of employment or redundancies. Changes in the companies may also include e.g. an increased flexibility of the economic profiles of the companies. The introduction of changes in the organisational structures of companies is the responsibility of creative, highly-qualified managers. The personality traits of these people as well as the intangible work they perform make them representatives of the creative class (Florida, 2002). The new organisational structures of companies born as a result of their decisions lead to the transformation of hierarchical structures into network ones (Napier, Nilsson, 2006), and the replacement of traditional company departments by temporary project groups of specialists (Kloosterman, 2010; Landry, 2006), among others. The arising new structures often trigger new work conditions, conducive to the development of creativity. This gives rise to a creative milieu within a company or an institution (Törnqvist, 2011).

Based on the interviews and questionnaires conducted within the framework of two international research projects (ACRE - Accommodating Creative Knowledge - Competitiveness of European Metropolitan Regions within the Enlarged Union and CREA.RE Creative Regions), the author defines the role of managers in the organisational changes in the creative sector companies and institutions in the Poznań metropolitan region.

Słowa kluczowe: kreatywne środowisko; menedżerowie; sektor kreatywny; zmiany organizacyjne

Key words: creative milieu; creative sector; managers; organizational changes

\section{WSTĘP}

Postępujące procesy globalizacji prowadzą do rosnącej konkurencji między firmami należącymi do różnych sektorów gospodarki. Zmieniające się wymagania rynku wymuszają na podmiotach gospodarczych należących do sektora usług i przemysłu wprowadzanie zmian, które często przyczyniają się do całkowitego przekształcenia ich struktury organizacyjnej. Przewidziane w ramach tych zmian działania wiążą się z dużym ryzykiem, wynikającym z niepewnych rezultatów, wzrostu niezadowolenia wśród pracowników czy w wielu przypadkach redukcji zatrudnienia. Jednocześnie przekształcenia wiążą się ze wzrostem elastyczności przedsiębiorstw w zakresie procesów produkcyjnych czy świadczonych usług.

Ożywiona dyskusja nad rolą kreatywności w rozwoju regionów przenosi się także na poziom struktur niższego rzędu - firm i instytucji sektora publicznego oraz niepublicznego. Zdaniem Floridy (2005) kreatywność, tj. ludzka twórczość, jest jednym z ważniejszych źródeł rozwoju społeczno-gospodarczego, w tym powstawania nowych firm i tworzenia w nich nowych miejsc pracy. W wyniku tego rozwoju pojawia się nowa stratyfikacja społeczno-ekonomiczna, w której coraz ważniejszą pozycję zajmuje tzw. klasa kreatywna (creative class). Wyróżniającą cechą tej klasy jest to, że jej członkowie angażują się w tworzenie nowych form działalności artystycznej i rozwiązań w zakresie działalności naukowo-badawczej, przy czym istotna część wartości dodanej takiej pracy ma charakter niematerialny (Florida, 2005: 34). Przedstawicielami tej klasy są pracownicy o wysokich kwalifikacjach, którzy stanowią m.in. kadrę menedżerską firm. Wprowadzane w wyniku ich decyzji zmiany prowadzą do wyłaniania się nowych struktur organizacyjnych w podmiotach gospodarczych, prowadzących działalność usługową i produkcyjną. Struktury hierarchiczne zostają zmienione w sieciowe (Napier, Nilsson, 2006). Zastępowaniu ulegają tradycyjne działy firm przez 
tymczasowo działające grupy projektowe, skupiające specjalistów z sektora kreatywnego (Kloosterman, 2010; Landry, 2006). Zmiany w firmach stanowią wyzwanie dla potencjału kreatywnego menedżerów, którzy są częścią wspomnianej wyżej nowej klasy społecznej, określanej mianem kreatywnej. Zagadnienie zmian w funkcjonowaniu i organizacji podmiotów podejmowane było już w licznych publikacjach dotyczących procesów restrukturyzacji polskiej gospodarki. W wielu z nich omawiano je, uwzględniając aspekt przestrzenny zmian, i rozpatrywano w szerokim ujęciu. Obejmowało ono regionalne zróżnicowanie zmian w całym sektorze gospodarki lub w jego wybranych gałęziach (m.in. Czapliński, 2008; Domański, Stryjakiewicz, 2003; Rachwał 2011, 2006; Tobolska, 2008; Wiedermann 2008; Zioło, 2008). Z kolei w ujęciu węższym problem zmian organizacyjnych odnoszono do wybranych przedsiębiorstw (m.in. Jaworski, 2006; Kilar, 2011). W niewielkim stopniu natomiast zagadnienie zmian w firmach lub instytucjach rozpatrywane było w odniesieniu do roli pracowników odpowiedzialnych za ich kreowanie oraz wprowadzanie, czyli menedżerów i tych pracowników, którzy są odbiorcami tych zmian, czyli pracowników niższego szczebla. Niniejszy artykuł stanowi próbę uzupełnienia tej luki.

Głównym jego celem jest przedstawienie roli menedżerów w zmianach organizacyjnych firm i instytucji sektora kreatywnego w poznańskim regionie metropolitalnym. Na tak ogólnie sformułowany cel składają się następujące cele szczegółowe o charakterze poznawczym:

1) określenie znaczenia przedstawicieli sektora kreatywnego i środowiska twórczego $\mathrm{w}$ zmianach organizacyjnych w podmiotach gospodarczych należących do sektora kreatywnego w świetle wybranych koncepcji teoretycznych,

2) charakterystyka menedżerów odgrywających istotną rolę w rozwoju firm sektora kreatywnego w poznańskim regionie metropolitalnym,

3) przedstawienie roli menedżerów w zmianach organizacyjnych w firmach i instytucjach sektora kreatywnego w zakresie wprowadzania nowych form i warunków zatrudnienia,

4) przedstawienie opinii menedżerów oraz podległych im pracowników dotyczących skutków zmian w organizacji firm lub instytucji publicznych i niepublicznych należących do sektora kreatywnego,

5) ukazanie ograniczeń dla wprowadzania zmian organizacyjnych związanych z funkcjonowaniem przedsiębiorstw oraz propozycje nowych zmian.

Tak sformułowane cele decydują o treści i strukturze niniejszego artykułu i zrealizowane zostaną dzięki wykorzystaniu wyników badań dwóch projektów: 1) ACRE - Accommodating Creative Knowledge. Competitiveness of European Metropolitan Regions within the Enlarged Union (Wykorzystanie kreatywnej wiedzy. Konkurencyjność europejskich regionów metropolitalnych w rozszerzonej Unii) ${ }^{1}$ i 2) CREA.RE - Creative Regions (Kreatywne regiony $)^{2}$.

${ }^{1}$ ACRE - międzynarodowy projekt badawczy 6. Programu Ramowego UE realizowany przez zespoły badawcze z 13 ośrodków metropolitalnych Unii Europejskiej, w tym przez zespół prof. Tadeusza Stryjakiewicza z Instytutu Geografii Społeczno-Ekonomicznej i Gospodarki Przestrzennej Uniwersytetu im. Adama Mickiewicza w Poznaniu (www.acre.socsci.uva.nl; 2010).

${ }^{2}$ CREA.RE Creative Regions - międzynarodowy projekt badawczy realizowany w latach 2010-2013. Wzięływ nim udział osoby reprezentujące 12 władz lokalnych i regionalnych z różnych regionów europejskich oraz 


\section{WYBRANE KONCEPCJE TEORETYCZNE DOTYCZĄCE WPŁYWU MENEDŻERÓW} NA CHARAKTER ZMIAN ORGANIZACYJNYCH W FIRMACH I INSTYTUCJACH ZWIĄZANYCH Z SEKTOREM KREATYWNYM

Głównym zagadnieniem, które zostało podjęte w niniejszym artykule, jest rola menedżerów w zmianach organizacyjnych firm sektora kreatywnego. Zarządzanie organizacją i wprowadzanie w niej zmian przez kreatywnych menedżerów może postępować zgodnie $\mathrm{z}$ orientacją procesową przyjmowaną w teorii zarządzania. W jej ramach zakłada się, że organizacja opiera się na działaniach, które składają sie na procesy, a jej nadrzędnym celem jest tworzenie wartości dla klienta, którym może być zarówno pracownik należący do organizacji, jak i osoba spoza niej, np. nabywca towaru (Nalepka, Ujwary-Gil, 2010).

Sposób, w jaki zostaną przeprowadzone zmiany w organizacji, oraz ich efektywność zależą w dużym stopniu od kreatywności osób, najczęściej menedżerów, którzy je podejmują. Problematyka kreatywności podejmowana była przez badaczy w różnych okresach i na gruncie różnych dziedzin nauki. W sztuce i literaturze mówi się głównie o wytworach kreatywności. Z kolei psychologowie zwracają szczególną uwagę na kreatywność osób i traktują ją jako działalność o charakterze procesowym. Z kolei w socjologii i w naukach społecznych podejmowane są badania związane z uwarunkowaniami rozwoju kreatywności. Próbę uogólnienia tych zagadnień podejmuje Florida (2002), którego zdaniem kreatywność, tj. ludzka twórczość, jest jednym z ważniejszych źródeł rozwoju społeczno-gospodarczego, w tym powstawania nowych firm i tworzenia nowych miejsc pracy. Rozwój kreatywności warunkuje występowaniem określonych cech miejsca, które zostały sprecyzowane w koncepcji 3T. Zgodnie z tą koncepcją kreatywność może się rozwijać w miejscu, gdzie obecne są: tolerancja, technologia i talent.

Törnqvist (2011) podejmuje próbę uogólnienia rozważań dotyczących rozwoju kreatywności we własnej koncepcji 4P. Istotną rolę odgrywają w niej takie elementy, jak: osoba, proces, produkt i miejsce (4 P - Person, Process, Product, Place). W niniejszym artykule uwagę skupiono głównie na trzech elementach tej koncepcji - osobie, procesie i miejscu. Mają one bowiem istotne znaczenie w przypadku kreatywnych działań, związanych ze zmianami organizacyjnymi w podmiotach sektora kreatywnego.

Mówiąc o pierwszym z elementów koncepcji, należy zwrócić uwagę, że za kluczowe zmiany w przedsiębiorstwach odpowiedzialne są kreatywne osoby - najczęściej menedżerowie, którzy tworzą jeden z najistotniejszych elementów organizacji. Wprowadzają nowe rozwiązania w zakresie prowadzenia firmy - innowacje, które są rezultatem ich kreatywności (ryc. 1). Najbardziej efektywni i dynamiczni z nich cechują się umiejętnościami w zakresie zarządzania, co wiąże się m.in. z utrzymywaniem dobrych relacji ze współpracownikami oraz posiadaniem dużej odwagi w podejmowaniu ryzykowanych decyzji. Drucker (1985: 27), nawiązując do Schumpetera i jego teorii dotyczącej roli przedsiębiorcy w tworzeniu innowacji, wskazuje na ryzyko związane z zarządzaniem przedsiębiorstwem i stwierdza, że: ,podstawą 
zdrowej gospodarki powinna być dynamiczna nierównowaga wywołana przez wprowadzającego innowacje przedsiębiorcę (menedżera), a nie równowaga i optymalizacja”.

\begin{tabular}{|c|}
\hline Kreatywność \\
\hline Proces \\
tworzenia \\
pomysłów
\end{tabular}

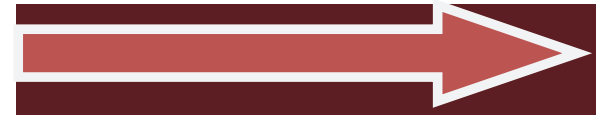

Kreatywna jednostka (kreatywny menadżer)

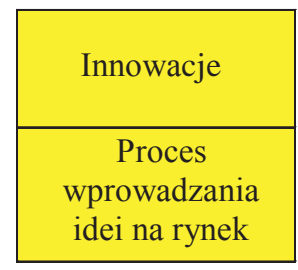

Ryc. 1. Udział menedżera w przejściu od kreatywności do innowacji

Źródło: opracowanie autora

Z drugim elementem koncepcji Törnqvista - procesem, wiąże się zagadnienie zmiany w organizacji. Zmiany w organizacji przedsiębiorstwa mogą mieć charakter procesowy i przebiegać w sposób ewolucyjny (Nalepka, Ujwary-Gil, 2010).

Ostatnim elementem omawianej koncepcji, istotnym z punktu widzenia wprowadzania zmian w organizacji firmy lub instytucji jest miejsce. W niniejszym artykule jest ono rozumiane jako środowisko, w którym działają kreatywni menedżerowie. Tworzone jest ono także przez jednostki o różnych cechach charakteru, które współpracują ze sobą w sposób uporządkowany i skoordynowany, aby osiągnąć określone cele (Griffin, 1996). Relacje oparte na współpracy między jednostkami w organizacji można podzielić na: 1) służbowe - łączące kierowników z ich podwładnymi, 2) techniczne (technologiczne) - łączące poszczególne stanowiska pracy, które uczestniczą w tym samym projekcie w różnych jego fazach, 3) funkcjonalne - więzi zachodzące pomiędzy stanowiskami lub grupami stanowisk realizującymi różne funkcje, 4) informacyjne - więzi zachodzące w zakresie wymiany informacji.

Wyniki licznych studiów świadczą o tym, że poznanie mechanizmów podejmowania zmian w organizacji przedsiębiorstw nie jest możliwe bez poznania reguł rządzących małymi grupami społecznymi, funkcjonującymi w działach przedsiębiorstw lub jednostek badawczych (Törnqvist, 2004). Charakter wykonywanej przez nie pracy i jej rezultaty mogą się różnić. O ile menedżerowie związani z działaniami twórczymi przyczyniają się do rozwoju kreatywności, o tyle osoby związane z nauką i gospodarką, dzięki swojej kreatywności tworzą innowacje. Zarówno w pierwszym, jak i drugim przypadku istotne znaczenie w podnoszeniu efektywności odgrywać będą dobrej jakości warunki pracy w miejscu zatrudnienia (umożliwiające m.in. swobodną wymianę informacji).

Stworzenie dobrych warunków pracy w przedsiębiorstwie opartych na kreatywnych menedżerach i zachodzących procesach przyczynia się do wytworzenia środowiska twórczego (creative milieu). Według Törnqvista (1983), takie środowisko cechują trzy rodzaje zasobów: (1) informacji (i łatwość przekazywania ich wewnątrz takiego środowiska); (2) wiedzy (oparty nie tylko na gromadzeniu informacji, ale też na akumulacji wiedzy w czasie, np. w ośrodkach uniwersyteckich); (3) kompetencji w zakresie określonych rodzajów działalności. Połączenie tych trzech zasobów jest warunkiem wyłonienia się czwartego - kreatywności, tj. zdolności 
tworzenia nowych form i wartości zarówno materialnych (np. produktów), jak i niematerialnych (np. wartości symbolicznych, pomysłów, idei; Stryjakiewicz, Stachowiak, 2010: 7).

Autor koncepcji twórczego środowiska - Törnqvist - zagadnienie kreatywności rozpatruje w swojej pracy pt. Creativity and the Renewal of Regional Life (1983) i odnosi je do skali miasta lub regionu. W późniejszych badaniach tenże autor (2004) wskazał, że twórcze środowisko można rozpatrywać w mniejszej skali niż miasto lub region, i odnosi swoje rozważania do przedsiębiorstwa. Taką skalę badań przyjęto także w niniejszym artykule. Törnqvist zauważył, że można mówić o korzyściach związanych z: 1) lokalizacją (m.in. bliskość przyrody), 2) sprzyjającym przedsiębiorczości otoczeniem instytucjonalnym (m.in. przejrzysty system podatkowy), oraz 3) przyjaznym klimatem współpracy między pracownikami (m.in. łatwość nawiązywania współpracy). Występowanie tak opisanego otoczenia pozwala na wprowadzenie kreatywnych rozwiązań. Prowadzi to do wzrostu konkurencyjności przedsiębiorstw, a w konsekwencji miast i regionów, na których terenie są zlokalizowane (Malecki, 1987).

\section{Metodologia BADAŃ}

Informacje dotyczące roli wybranych menedżerów w zmianach organizacyjnych przedsiębiorstw sektora kreatywnego w poznańskim regionie metropolitalnym uzyskano na podstawie wyników badań ankietowych (w odniesieniu do pracowników sektora kreatywnego) oraz pogłębionych wywiadów (w odniesieniu do menedżerów i migrantów zagranicznych związanych z sektorem kreatywnym). Badania te przeprowadzono w ramach dwóch projektów międzynarodowych: ACRE i CREA.RE Creative Regions.

Pierwszy z projektów realizowany był w latach 2006-2010 i uczestniczyły w nim zespoły naukowców z 13 regionów metropolitalnych w Europie, w tym z Uniwersytetu im. Adama Mickiewicza w Poznaniu. Poznański zespół kierowany był przez profesora Tadeusza Stryjakiewicza.

W badaniach ankietowych przeprowadzonych w ramach projektu ACRE w lipcu i sierpniu 2007 r. na terenie poznańskiego regionu metropolitalnego (PRM) wzięło udział łącznie 200 pracowników sektora kreatywnego (100 przedstawicieli działalności twórczych i 100 przedstawicieli działalności o dużym wykorzystaniu wiedzy), co stanowiło 0,2\% ogólnej liczby pracujących w tym sektorze na analizowanym obszarze. Ponadto w niniejszym artykule wykorzystano wyniki badań opierających się na wywiadach pogłębionych, przeprowadzonych również w ramach projektu ACRE. Uczestniczyło w nich łącznie 50 osób, w tym - 20 menedżerów firm sektora kreatywnego, 25 migrantów transnarodowych i 5 ekspertów zajmujących się problematyką migracji osób twórczych i o wysokich kwalifikacjach. Wywiady były prowadzone w marcu 2008 i w lutym 2009 r. Szczegółowy opis doboru próby badawczej do ankietowych i opierających się na wywiadach pogłębionych w ramach projektu ACRE został przedstawiony w publikacji Stryjakiewicza i Męczyńskiego (2010).

Dzięki drugiemu z projektów - CREA.RE Creative Regions - możliwa była aktualizacja i rozszerzenie wiedzy dotyczącej sektora kreatywnego w PRM. W ramach jego realizacji 
w styczniu 2012 r. przeprowadzono 10 wywiadów pogłębionych z reprezentantami sektora kreatywnego.

\section{WYBRANI MENEDŻEROWIE SEKTORA KREATYWNEGO I ICH ROLA W POZNAŃSKIM REGIONIE METROPOLITALNYM}

Badania ankietowe prowadzone w ramach projektu ACRE pozwoliły wskazać najbardziej kreatywnych menedżerów w poznańskim regionie metropolitalnym. Respondenci W większości kojarzyli kreatywność z działalnością artystyczną i kulturalną. W związku z tym w gronie jedenastu wskazanych przez respondentów osób znaleźli się w większości menedżerowie reprezentujący podsektor działalności twórczych. Zaledwie cztery ze wskazane osób związane były z podsektorem działalności o dużym wykorzystaniu wiedzy.

W trójce najczęściej wymienianych osób znalazła się Pani Grażyna Kulczyk, która wraz z Panem Janem Kulczykiem została uznana za najbardziej kreatywnego menedżera. Jest ona założycielem i wyłącznym udziałowcem od 1998 r. firmy Fortis Sp. z o.o., właściciela Centrum Handlu, Biznesu i Sztuki - Stary Browar, miejsca, które łączy biznes i sztukę. Podjęte przez Panią Kulczyk działania spowodowały zaangażowanie 27 firm na etapie przygotowania projektu Starego Browaru i jego realizacji. Pozwoliło to stworzyć 400 nowych miejsc pracy. W pierwszej, otwartej części obiektu - Atrium Starego Browaru miejsce pracy znalazło 1300 osób. Po otwarciu drugiej części obiektu w 2007 r. - Pasażu Starego Browaru - liczba zatrudnionych osiągnęła łącznie 2500 osób. W 2012 r. zatrudnienie osiągnęło 4000 pracowników. Pani Kulczyk, prowadząc Stary Browar, łączy działalność biznesową z animacją, patronatem wydarzeń artystycznych i kulturalnych w mieście (m.in. wystaw rzeźby i malarstwa, spektakli teatralnych i operowych, koncertów muzycznych, www.starybrowar5050.com, 2012). Część kolekcji Grażyny Kulczyk stanowi wyposażenie galerii sztuki nowoczesnej w Starym Browarze.

Jan Kulczyk jako jeden z najbogatszych Polaków (www.100najbogatszych.wprost.pl, 2012) również należy do osób, których działania przyczyniają się do podnoszenia konkurencyjności poznańskiego regionu metropolitalnego. Jest właścicielem Kulczyk Investments - spółki matki, zarejestrowanej w 2007 roku w Luksemburgu. Zajmuje się zarządzaniem spółkami grupy, działającymi na arenie międzynarodowej w najbardziej atrakcyjnych sektorach gospodarki: energetyka, surowce mineralne, infrastruktura i nieruchomości. Kulczyk Holding, jako podmiot zależny od Kulczyk Investments, koncentruje 22 spółki działające na terenie Polski (www.kulczykinvestments.com, 2012). Bierze także udział w akcjach charytatywnych Fundacji Rodziny Kulczyków, która przyznaje stypendia studentom i młodym naukowcom z Poznania.

W trójce osób uznanych przez respondentów za kreatywne znalazł się Krzysztof Olszewski. Założyciel, długoletni prezes zarządu i dyrektor generalny spółki Solaris Bus \& Coach S.A. (do 2001 r. Neoplan Polska Sp. z o.o.), a obecnie przewodniczący Rady Nadzorczej. W ostatnim dziesięcioleciu stworzył markę będącą symbolem możliwości 
przemysłowych poznańskiego regionu metropolitalnego. Autobusy marki Solaris znajdują nabywców w Polsce i za granicą, m.in.: w Niemczech, Estonii, Emiratach Arabskich.

Wśród wymienianych przez respondentów osób, związanych z sektorem biznesowym, ale łączących tę działalność z mecenatem sztuki znalazł się Piotr Voelkel. Swoje zainteresowania związane z finansowaniem sztuki może realizować, zarabiając na produkcji mebli, okładzin ściennych i boazerii. Voelkel ma obecnie akcje dające 51\% głosów w Grupie Kapitałowej Vox. W jej skład wchodzą m.in. Vox-Industrie, Vox-Chemia i Składy Budowlane Vox sp. z o.o. Firmę założył w 1989 r. Wcześniej był właścicielem przedsiębiorstwa wytwarzającego galanterię z kości, rogów, surowców miejscowych i odpadowych. Voelkel ma także udziały w poznańskich stacjach radiowych Kiss FM i 88,4 FM i jest założycielem Wyższej Szkoły Nauk Humanistycznych i Dziennikarstwa w Poznaniu. W 2006 r. zajmował 61. pozycję na liście 100 najbogatszych Polaków tygodnika „Wprost” z majątkiem $300 \mathrm{mln}$ zł (www.kulczykinvestments.com, 2012).

Wśród najbardziej kreatywnych według respondentów menedżerów działalności twórczych jest też Ewa Wycichowska - tancerka, choreograf, pedagog. Ukończyła Państwową Szkołę Baletową w Poznaniu i Akademię Muzyczną w Warszawie. Studiowała taniec modern w L’Academie de la Danse w Paryżu u Yuriko i Petera Goosa. Była primabaleriną Teatru Wielkiego w Łodzi. Jest członkiem Międzynarodowej Rady Tańca, działającej pod patronatem UNESCO (www.culture.pl, 2012).

Rola Michała Merczyńskiego jako dyrektora Międzynarodowego Festiwalu Teatralnego Malta w latach 90. XX w. dobrze utkwiła w pamięci respondentów uczestniczących w badaniach ankietowych. Znalazł się on także w grupie osób, które wprowadzając zmiany w swojej działalności, miały istotny wpływ na podnoszenie konkurencyjności PRM. Merczyński jest absolwentem kulturoznawstwa na Uniwersytecie im. Adama Mickiewicza w Poznaniu (1980-1985). Po studiach rozpoczął pracę w Państwowym Teatrze Polskim w Poznaniu jako menedżer Orkiestry Ósmego Dnia. Wraz z nią przyczynił sie do zorganizowania m.in. koncertów w Amsterdam Paradis, londyńskiej Queen Elisabeth Hall oraz dwóch superprodukcji multimedialnych: „Czekając na Kometę Halleya” i „Symfonię solo”. Od 2002 roku jest dyrektorem naczelnym Teatru Rozmaitości w Warszawie (www.nina.gov.pl, 2012).

Do grona osób rozpoznawalnych przez respondentów należała także Urszula Sipińska. Znana w skali ogólnopolskiej i międzynarodowej piosenkarka, kompozytorka oraz pianistka. Ukończyła klasę fortepianu w Wielkopolskim Studium Muzycznym oraz Wydział Architektury Wnętrz PWSSP w Poznaniu. W czasie studiów współpracowała ze studenckim teatrzykiem „Nurt”. W późniejszym okresie koncertowała jako piosenkarka na całym świecie, zdobywała liczne nagrody na festiwalach. Zakończyła karierę estradową w 1990 roku i poświęciła się architekturze.

Jedynym rozpoznawalnym cudzoziemcem wskazywanym przez respondentów jako kreatywny menedżer był Robert Gamble - Amerykanin szkocko-irlandzkiego pochodzenia. Po raz pierwszy przyjechał do Polski jeszcze na studiach - „na egzotyczne wakacje za żelazną kurtyną". Od tamtego czasu utrzymywał bliskie kontakty ze swoimi polskimi przyjaciółmi i odwiedził Polskę jeszcze kilka razy. W Stanach Zjednoczonych został pastorem Amerykańskiego Protestanckiego Kościoła Episkopalnego. W latach 80. XX w. 
zaangażowany był w rozwój ruchu Anonimowych Alkoholików w Polsce, pomagając im W nawiązywaniu kontaktu ze specjalistami amerykańskimi. W 1992 w związku z decyzją o sponsorowaniu Radia Obywatelskiego w Poznaniu podjął decyzję o przeniesieniu się na pewien czas do Polski. W tym samym okresie założył wydawnictwo Media Rodzina, aby wydać po polsku książkę Adele Faber i Elaine Mazlish pt. Jak mówić, żeby dzieci nas stuchały. Jak stuchać, żeby dzieci do nas mówity. Wydawnictwo wydało ponadto Opowieści z Narnii C.S. Lewisa oraz Harry'ego Pottera J.K. Rowling. Robert Gamble pragnie wydawać książki „opierające się na wartościach chrześcijańskich, ale takich, które mogą zaakceptować również niewierzący lub wątpiący” (wywiad z Robertem Gamble przeprowadzony w marcu 2008 r.).

W gronie rozpoznawalnych osób, które nie tylko są dobrymi menedżerami, ale także społecznikami, działaczami, prowadzącymi różne przedsięwzięcia społeczne znaleźli się także Andreas Billert - historyk sztuki, zaangażowany w działania mające na celu rewitalizację miasta Poznania, oraz Jan Góra, dominikanin, twórca spotkań młodzieży na Lednicy.

\section{DZIAŁANIA KREATYWNYCH MENEDŻERÓW ZWIĄZANE Z WPROWADZANIEM} ZMIAN W ZAKRESIE POPRAWY RELACJI FIRM I INSTYTUCJI SEKTORA KREATYWNEGO Z OTOCZENIEM

Budowanie współpracy podmiotów sektora kreatywnego z otoczeniem jest procesem długotrwałym i najczęściej opiera się na formalnych i nieformalnych kontaktach osób zarządzających przedsiębiorstwami lub instytucjami. Wprowadzanie zmian w tym zakresie jest zatem procesem długofalowym, opierającym się na budowaniu wzajemnego zaufania.

Wyniki przeprowadzonych badań pozwoliły stwierdzić, że większość podmiotów sektora kreatywnego związana jest od lat z Poznaniem i jego mieszkańcami. Często w integracji sektora kreatywnego z otoczeniem pomagają zmiany w sposobach komunikacji dzięki zastosowaniu nowoczesnych technologii informacyjno-komunikacyjnych.

Centrum Kultury „Zamek” stosuje różnorodne kanały dotarcia do potencjalnych odbiorców. Najważniejsze z nich to: profil na Facebooku z oddzielnymi podstronami [...], reklama w radio i (rzadziej) w telewizji, plakaty i ulotki (umieszczane w klubach, na uczelniach, w instytucjach kulturalnych, na nośnikach zewnętrznych - m.in. na zachodniej elewacji wieży Centrum), kontakt z mediami, imienne zaproszenia oraz organizacja konferencji prasowych (wypowiedź dyrektora Centrum Kultury Zamek, 2012).

Wydział Działalności Gospodarczej Urzędu Miasta Poznania prowadzi portal internetowy: www.wpi.poznan.pl, który pełni funkcję informacyjną (wypowiedź przedstawiciela Wydziału Działalności Gospodarczej Urzędu Miasta Poznania, 2012).

Badani menedżerowie instytucji związanych z sektorem kreatywnym stwierdzali, że dzięki nowoczesnym technologiom informacyjno-komunikacyjnym i ich sprawnemu zarządzaniu możliwa jest zmiana formy promocji marki Poznań. Według nich istnieją duże 
możliwości w zakresie przygotowania profesjonalnej strony oraz platformy internetowej dla przedsiębiorców, w tym działających w sektorze kreatywnym.

Jako rozwiązanie problemów proponuję m.in. pracę nad komunikacją i zwiększeniem zaufania (partnerów projektów). W celu zbudowania lepszego zaufania istotna jest poprawa transparentności działań partnerów. [...] Poprzez tworzenie silnej marki przedsiębiorstw możliwe będzie tworzenie silnej marki naszego regionu. W tym zakresie powinny być podejmowane działania promujące innowacyjność. Dobrym przykładem są związane z innowacjami konkursy organizowane m.in. przez Urząd Miasta Poznania. Dużą rolę odgrywa też platforma internetowa dla przedsiębiorców. Wszystkie z wymienionych działań mają charakter długofalowy (wypowiedź przedstawiciela Biura Promocji Urzędu Miasta Poznania, 2012).

Zadania związane ze zmianami organizacyjnymi w przedsiębiorstwie prowadzone są nie tylko na zewnątrz firmy lub przedsiębiorstwa. Duże znacznie mają także działania prowadzone wewnątrz organizacji, m.in. przez tworzenie twórczego środowiska w miejscu pracy.

\section{TWORZENIE TWÓRCZEGO ŚRODOWISKA W MIEJSCU PRACY}

Florida (2002) uważa, że większość pracowników sektora kreatywnego można uznać za przykład „modelowych przedsiębiorców”. Jednym z przejawów niezależności przedsiębiorców należących do sektora kreatywnego jest tryb ich pracy. W wielu przypadkach nie jest on regulowany czasowo. Jednocześnie praca w sektorze kreatywnym daje dużą swobodę w zakresie wewnętrznej organizacji zadań i realizacji własnych pomysłów (Gill, Pratt, 2008). Te aspekty pracy są często postrzegane przez badanych pracowników jako korzyści zatrudnienia w omawianym sektorze.

Przeprowadzone badania ankietowe oraz wywiady pozwoliły określić wpływ, jaki mają działania menedżerów sektora kreatywnego na warunki pracy ich samych oraz innych zatrudnionych. Zmiany wprowadzane w firmach i instytucjach służyć miały podnoszeniu jakości warunków zatrudnienia i tworzeniu twórczego środowiska w miejscu pracy.

W wyniku przeprowadzonych badań ankietowych stwierdzono, że w poznańskim regionie metropolitalnym udział osób zatrudnionych tymczasowo wynosił 43\% (na czas określony, m.in. w ramach realizacji projektów, umów o dzieło, umów zlecenia). Ponad jedna trzecia respondentów była samozatrudniona (31,6\%). Jednocześnie mężczyźni wykazywali większą skłonność do tej formy zatrudnienia (30,7\%) niż kobiety (20,9\%). Wśród kobiet widoczna była jednak większa stabilność zatrudnienia, gdyż tylko niewiele ponad $30 \%$ z nich było zatrudnionych tymczasowo (Brown, Nadler, Męczyński, 2010). Sprzyjało to możliwości zakładania rodziny, posiadaniu i wychowaniu dzieci. W przypadku blisko 70\% kobiet, które pracowały w sektorze kreatywnym, zatrudnienie na czas nieokreślony dawało możliwość korzystania ze świadczeń proponowanych ze strony państwa. Dostępność różnego typu świadczeń wysoko oceniane było przez ogół ankietowanych (55,3\% respondentów; tab. 2). Za największą korzyść uczestnicy badań uznali jednak możliwość wpływu na własną pracę (77,6\% ankietowanych). 
Tab. 2. Zadowolenie z warunków zatrudnienia pracowników sektora kreatywnego w poznańskim regionie metropolitalnym

\begin{tabular}{|l|c|c|c|}
\hline \multicolumn{1}{|c|}{ Aspekt zadowolenia } & $\begin{array}{c}\text { Udział osób } \\
\text { zadowolonych } \\
\text { (w \%) }\end{array}$ & $\begin{array}{c}\text { Udział osób } \\
\text { niezadowolonych } \\
(\mathrm{w} \%)\end{array}$ & $\begin{array}{c}\text { Ogółem } \\
\text { (w \%) }\end{array}$ \\
\hline $\begin{array}{l}\text { Zabezpieczenia pracownicze } \\
\text { i socjalne }\end{array}$ & 55,3 & 44,7 & 100 \\
\hline Poziom wynagrodzeń & 48,7 & 51,3 & 100 \\
\hline Możliwości rozwoju zawodowego & 37,0 & 63,0 & 100 \\
\hline $\begin{array}{l}\text { Możliwości uczestnictwa } \\
\text { W dodatkowych szkoleniach }\end{array}$ & 39,7 & 60,3 & 100 \\
\hline $\begin{array}{l}\text { Możliwość pogodzenia pracy z życiem } \\
\text { osobistym }\end{array}$ & 46,7 & 53,3 & 100 \\
\hline Możliwość tworzenia sieci współpracy & 58,1 & 41,9 & 100 \\
\hline $\begin{array}{l}\text { Możliwość wpływu } \\
\text { na wykonywana pracę }\end{array}$ & 77,6 & 22,4 & 100 \\
\hline Poczucie spełnienia zawodowego & 63,2 & 36,8 & 100 \\
\hline
\end{tabular}

Źródło: projekt ACRE, ze zmianami autora

Mimo wysokiego poziomu niepewności zatrudnienia i ryzyka jego utraty duża liczba wysoko wykwalifikowanych, głównie młodych osób poszukuje pracy w sektorze kreatywnym, a w szczególności w działalnościach twórczych. Pociąga ich kojarzony z pracą w tym sektorze wizerunek aktywnej, dynamicznej i przedsiębiorczej osoby, która posiada duży zakres autonomii w podejmowaniu różnego typu działań. Praca w sektorze kreatywnym daje duże możliwości samorealizacji i wykorzystania własnych umiejętności. Charakter takiej pracy wiąże się także z prestiżem, gdyż w przekonaniu wielu osób tylko nieliczni posiadają talent lub wyjątkowe kwalifikacje i mogą należeć do grona tzw. wybranych (McRobbie, 1998).

Charakter pracy menedżera w sektorze kreatywnym wiąże się także z emocjami, które mu towarzyszą. Kocowski (1991) wskazuje na te, które przyczyniają się do nowych pomysłów. Emocje te wynikają z atmosfery panującej w miejscu pracy i obejmują zaciekawienie, radość, sympatie interpersonalne i inne pozytywne czynniki pobudzające kreatywne działania.

Wyniki wywiadów przeprowadzonych w przedsiębiorstwach i instytucjach znajdujących się na terenie poznańskiego regionu metropolitalnego pozwoliły stwierdzić, że atmosfera tworzona przez współpracowników w miejscu zatrudnienia wywoływała pozytywne emocje. Przyczyniały się one do silnego zaangażowania menedżerów w realizację stawianych przed nimi celów (tab. 3). Traktowali je jednocześnie jako wyzwania, którym muszą sprostać i poświęcić cały swój potencjał kreatywny. Istotnym czynnikiem rozwoju było poczucie wolności w podejmowaniu nowych działań. Część emocji związanych z miejscem pracy miała jednak niekorzystny wpływ na prowadzących podmioty gospodarcze i przyczyniała się do wzbudzenia w nich dużych obaw związanych z prezentacją własnych planów lub projektów oraz możliwości ich odrzucenia. Sytuacja ta miała miejsce mimo wskazywania w pracy swobodnej atmosfery do dyskusji dotyczącej podejmowania nowych działań. 
Tab. 3. Warunki pracy i możliwości realizacji celów menedżerów sektora kreatywnego w poznańskim regionie metropolitalnym

\begin{tabular}{|c|c|c|}
\hline Aspekt kreatywności & $\begin{array}{c}\text { Poziom } \\
\text { występowania* }\end{array}$ & Wypowiedzi uczestników badań \\
\hline $\begin{array}{l}\text { Cel jest wyzwaniem dla } \\
\text { menedżera }\end{array}$ & ++ & $\begin{array}{l}\text { „TV kształtuje gust estetyczny [...]. Tak więc szuka } \\
\text { się seriali, które się wyróżniają, które są inne. Czegoś, } \\
\text { co nie będzie kolejnym powieleniem tego samego. Co } \\
\text { nie będzie powtórzeniem tej samej estetyki, tej samej } \\
\text { plastyki. [...] I myślę, że tu jest nasza siła. Siła kre- } \\
\text { atywności”. }\end{array}$ \\
\hline $\begin{array}{l}\text { Poczucie braku skrępo- } \\
\text { wania } \\
\text { i wolności działania pod- } \\
\text { czas podejmowania ini- } \\
\text { cjatyw i nowych zadań }\end{array}$ & ++ & $\begin{array}{l}\text { „U nas nie ma filmów }[\ldots] \text {, które powielają ten sam } \\
\text { pomysł. [...] Taka możliwość artystycznego wyżycia } \\
\text { się jest szalenie motywująca dla młodych ludzi”. }\end{array}$ \\
\hline $\begin{array}{l}\text { Wsparcie ze strony } \\
\text { współpracowników i pod- } \\
\text { władnych dla nowych } \\
\text { pomyslów }\end{array}$ & + & $\begin{array}{l}\text { „To nie jest duża firma, to nie jest korporacja, jest } \\
\text { to jeszcze firma rodzinna. Staram się żeby nie było } \\
\text { «wyścigu szczurów», żeby nie było takiej osoby, ko- } \\
\text { goś wprowadzającego taką atmosferę. Ważne jest za- } \\
\text { ufanie, szczególnie do osób istotnych w działalności } \\
\text { firmy. One muszą dobrze działać i musimy się rozu- } \\
\text { mieć. Wszystkie napięcia staram się jak tylko mogę, } \\
\text { czasem «po ludzku», a czasem odgórnie rozładow- } \\
\text { wać. Jak zrobi sto godzin, ma sto godzin razy stawkę. } \\
\text { Jeżeli sto pięćdziesiąt godzin, tak samo”. }\end{array}$ \\
\hline $\begin{array}{l}\text { Lęk zgłaszania nowych } \\
\text { pomysłów z powodu } \\
\text { ośmieszenia }\end{array}$ & - & $\begin{array}{l}\text { „[Młodzi absolwenci] są tak zamknięci na rynek, że } \\
\text { nie są w stanie pokonać oporu «pracy na zamówienie» } \\
\text { w profesjonalnym studiu z profesjonalnym zespołem. } \\
\text { Jakby hańbą dla artystów była praca za pieniądze”. }\end{array}$ \\
\hline $\begin{array}{l}\text { Możliwość dyskusji } \\
\text { w swobodnej atmosferze }\end{array}$ & ++ & $\begin{array}{l}\text { Dyskutujemy dziś o pewnych kwestiach podatko- } \\
\text { wych, o rozwoju miasta, np. nowych obiektach po- } \\
\text { wstających w mieście i możliwości prowadzenia dzia- } \\
\text { łalności w tych obiektach". }\end{array}$ \\
\hline $\begin{array}{l}\text { Tolerancja ze strony } \\
\text { podwladnych dla wystę- } \\
\text { powania sytuacji nie do } \\
\text { końca zdefiniowanych } \\
\text { i niepewnych }\end{array}$ & + & $\begin{array}{l}\text { „W ostatnich trzech, czterech latach obserwuje- } \\
\text { my mniejsze zainteresowanie firm zewnętrznych, } \\
\text { bo firm lokalnych powstało więcej i zwiększyła się } \\
\text { konkurencja w tzw. drugiej generacji spółek. Mamy } \\
\text { co jakiś czas zlecenia, np. z Płocka, ze Śląska czy } \\
\text { z Wrocławia, jednak takie firmy pojawiają się już co- } \\
\text { raz rzadziej”. }\end{array}$ \\
\hline
\end{tabular}

* ++ bardzo wysoki, + wysoki, - brak

Źródło: projekt ACRE, ze zmianami autora 


\section{WNIOSKI I PROPOZYCJE ZMIAN W POLITYCE WŁADZ LOKALNYCH}

\section{NA RZECZ ROZWOJU SEKTORA KREATYWNEGO W POZNAŃSKIM REGIONIE}

\section{METROPOLITALNYM}

Istnieje ciągła potrzeba wprowadzania zmian w organizacji firm i instytucji związanych z sektorem kreatywnym w celu podniesienia ich konkurencyjności. Jednocześnie zmiany te muszą być wprowadzane stopniowo. Wymaga to wykorzystania potencjału kreatywności menedżerów firm i instytucji, aby zmiany przeprowadzane były w sposób odpowiedzialny i przewidywalny.

Wyniki badań przeprowadzonych w ramach projektów ACRE i CREA.RE wśród menedżerów i pracowników sektora kreatywnego w poznańskim regionie metropolitalnym wskazują na postępujące zmiany związane z formą zatrudnienia i jakością miejsca pracy. W dynamicznie rozwijającym się na terenie poznańskiego regionu metropolitalnego sektorze kreatywnym wysoki jest udział zatrudnionych na czas określony, tymczasowo. Jednocześnie wysokość wynagrodzeń pracowników zatrudnionych tymczasowo jest niższa niż zatrudnionych na pełnym etacie na czas nieokreślony. Blisko połowa ankietowanych pracowników kreatywnego sektora gospodarki pracuje dłużej niż średnia liczba godzin pracy przypadająca na zatrudnionego w UE (37,9 godzin/tydzień, Employment Outlook, 2007). Postępujące zmiany w systemie zatrudnienia wywołują niezadowolenie dużej liczby pracowników sektora kreatywnego. Ulega ono pogłębieniu z powodu pogarszających się zabezpieczeń społecznych i pracowniczych, poziomu wynagrodzeń, możliwości rozwoju zawodowego i podnoszenia kwalifikacji

Część uczestników badań odnosi sukces w pracy zawodowej, jednak bardzo liczna grupa pracowników boryka się z problemami finansowymi i wykorzystywaniem przez pracodawców. Jednocześnie praca w sektorze kreatywnym, w szczególności w działalnościach twórczych lub artystycznych, daje zadowolenie z ,poczucia spełnienia zawodowego" i „możliwości wpływu na wykonywaną pracę”.

Zmiany dotyczące form zatrudnienia, ale także odnoszące się do całego sektora kreatywnego wymagają sformułowania długookresowych planów i strategii rozwoju. W ich ramach powinny zostać ujęte działania i projekty, które przyczynią się do wzrostu konkurencyjności firm i instytucji związanych z omawianym sektorem. Uczestniczący w badaniach przedstawiciele sektora kreatywnego nie tylko określili problemy, z jakimi się borykają, ale potrafili także wskazać sposoby ich rozwiązywania, proponując zmiany organizacyjne. Problemy, które zostały wskazane, można sklasyfikować w ramach dwóch kategorii.

Pierwsza kategoria dotyczy zagadnień związanych z integracją i budowaniem relacji z partnerami w sektorze kreatywnym na terenie miasta Poznania i jego regionu metropolitalnego. Druga kategoria problemów skupia się wokół polityki miasta związanej ze wsparciem dla sektora kreatywnego, w szczególności działalności twórczej.

Mówiąc o pierwszej kategorii, należy zauważyć, że jedną z cech współczesnej przestrzeni społeczno-ekonomicznej jest złożoność relacji występujących między uczestnikami gry ekonomicznej (m.in. przedsiębiorstwami, instytucjami i organizacjami). Budowanie sieci 
współpracy, opartej na rozwiniętych relacjach podmiotu gospodarczego z otoczeniem, jest procesem długotrwałym i postępuje z wykorzystaniem formalnych i nieformalnych kontaktów osób. Często właśnie nieformalne powiązania rodzinne i przyjacielskie stanowią istotny czynnik, warunkujący założenie własnego biznesu.

Rozwijaniu formalnych i nieformalnych kontaktów sprzyja bliskość przestrzenna uczestników sieci. Jak wskazują Stolarick i Florida (2006), to najczęściej zwarta przestrzeń miejska charakteryzuje się bliskością jednostek i umożliwia częsty kontakt bezpośredni osób. Dzięki tym kontaktom możliwe jest powstawanie struktur sieciowych opartych na współpracy biznesowej. Jakość i trwałość relacji w sieci uzależnione są natomiast od potencjału kreatywnego jednostek. Rozwinięte sieci kontaktów biznesowych w znacznym stopniu warunkują sukces przedsiębiorstwa (Bathelt i in., 2004). Zagadnienie to było często poruszane przez osoby uczestniczące w wywiadach.

Networking, sieć powiązań instytucji publicznych i prywatnych tworzy nową wartość. Wzajemne uzupełnianie się funkcji: instytucje publiczne - edukacja dotycząca własności intelektualnej, wzmacnianie świadomości wagi sektora kreatywnego dla rozwoju gospodarki oraz działalność podmiotów gospodarczych, związanych z sektorem kreatywnym. Chodzi w tym wypadku o konkretną działalność komercyjną (wypowiedź przedstawiciela Urzędu Miasta Poznania, 2012).

Jednym ze sposobów przełamania oporu związanego z podejmowaniem współpracy i łączeniem kapitału publicznego i prywatnego jest większa integracja środowisk biznesowych z sektorem kreatywnym, w tym przede wszystkim z przedstawicielami działalności twórczych. Jednym z takich rozwiązań mogłoby być powołanie miejsca określanego mianem rezydencji artystycznej (Centrum Kultury Zamek, 2012). Miałoby ono na celu nie tylko integrację osób prowadzących działalność twórczą, ale także tzw. mecenasów sztuki. Ci ostatni mieliby możliwość zapoznania się z dorobkiem artystów i ewentualnym dofinansowaniem lub współfinansowaniem, w powiązaniu z instytucjami publicznymi ich działalności.

Duże możliwości w zakresie integracji osób związanych z sektorem kreatywnym daje współcześnie Internet. Menedżerowie firm sektora kreatywnego wykazywali chęć podjęcia działań mających na celu stworzenie platformy internetowej, służącej zbliżeniu różnych podmiotów związanych z omawianym sektorem. Platforma taka miałaby umożliwić wymianę informacji między przedstawicielami sektora, dotyczących prowadzonych przez nich działań oraz możliwości podejmowania wspólnych przedsięwzięć.

Działania integracyjne przedstawicieli firm i instytucji należących do sektora kreatywnego służyć mają także rozwiązywaniu drugiego typu problemów, dotyczących polityki miasta związanej ze wsparciem dla tego sektora. Polityki, która powinna dotyczyć zmiany wizji jego rozwoju, opartej na wspólnych działaniach przedstawicieli tego sektora i przedstawicieli władz lokalnych. Brakuje bowiem w Polsce spójnej polityki tego rodzaju, wpisanej w całościową strategię rozwoju kraju, regionu i miasta. Brakuje także rozwiązań, w postaci dokumentów strategicznych, które sprzyjałyby tworzeniu przestrzeni kreatywnych (związanych z małą architekturą, przyjazną przestrzenią publiczną), w których mogliby spotykać się i działać przedstawiciele sektora kreatywnego. Wśród przedstawicieli można dostrzec niezadowolenie z niedoceniania i niewykorzystywania pomysłów mieszkańców Poznania. Niestety, często bardziej przyjazne dla rozwoju kreatywności uwarunkowania 
instytucjonalne, jakość otoczenia i atrakcyjniejsza oferta pracy, głównie w Warszawie, przyczyniają się do ucieczki z miasta twórczych młodych ludzi, tzw. talentów.

W związku z tym menedżerowie firm i instytucji związanych z sektorem kreatywnym wskazywali, że polityka władz lokalnych powinna ulec zmianie i być nastawiona w szczególności na większe wsparcie działalności związanych z tym dynamicznie rozwijającym się sektorem. Wiązać się to powinno ze wzrostem nakładów finansowych i wprowadzeniem udogodnień instytucjonalnych i organizacyjnych. Ponadto zaproponowano powielenie rozwiązań z innych miast, m.in. z Wrocławia (np. wprowadzenie polityki regulującej wysokość czynszów w lokalach należących do miasta, a wynajmowanych przez firmy i instytucje związane z sektorem kreatywnym).

Czynsze, zwłaszcza w obiekcie wykorzystywanym na cele kulturalne, powinny być ustalane w oparciu o wpisaną w status działalność o charakterze misji publicznej. Należy wziąć pod uwagę klasyfikację w systemie REGON (PKD) i nieustalanie dla podmiotów zajmujących się funkcją kulturalną czynszów komercyjnych. Rozwiązania takie są stosowane we Wrocławiu (wypowiedź przedstawiciela TV Studio Filmów Animowanych, 2012).

Wprowadzenie rozwiązań, które umożliwiłyby tani wynajem lokali na działalność związaną z sektorem kreatywnym, pomogłoby w powstawaniu obiektów przeznaczonych m.in. dla artystów. Ze względu na większą koncentrację, wynikającą z bliskości przestrzennej w centrum miasta, możliwy byłby swobodniejszy przepływ myśli i realizacja wspólnych projektów. Dzięki temu możliwe stałoby się tworzenie przestrzeni publicznej, korzystającej z potencjału tkwiącego w przedstawicielach klasy kreatywnej.

\section{Literatura}

Bathelt, H., Malmberg, A., Maskell, P. (2004). Clusters and Knowledge: Local Buzz, Global Pipelines and the Process of Knowledge Creation. Progress in Human Geography, 28, 31-56.

Brown, J., Męczyński, M. (2009). 'Complexcities': Locational Choices of Creative Knowledge Workers. W: C. Chapain, C. Collinge, P. Lee, S. Musterd (ed.), Can We Plan the Creative Knowledge City? Built Environment, 35 (2), 238-252.

Brown, J., Nadler, R., Męczyński, M. (2010). Working on the Edge? Creative Jobs in Birmingham, Leipzig and Poznan. W: S. Musterd, A. Murie (eds.), Making Competitive Cities. Oxford: Wiley Blackwell, 201-231.

Czapliński, P. (2008). Zmiany struktury przestrzennej przemysłu w subregionie słupskim. Prace Komisji Geografii Przemystu Polskiego Towarzystwa Geograficznego, 10, 23-35.

Domański, B., Stryjakiewicz, T. (2003). Postcommunist Industrial Transformation and Its Regional Dimension. W: G. Stöber (Hrsg.), Der Transformationsprozess in (Ost-)Deutschland und in Polen. Hannover: Verlag Hahnsche Buchhandlung, 46-71.

Drucker, P. (1985). Innovation and Entrepreneurship. Practice and Principles. New York: Harper $\&$ Row Publishers.

Employment Outlook, (2007). Paris: OECD. Pozyskano: http://www.oecd.org/els/oecdemploymentoutlook-downloadableeditions 1989-2011.htm

Florida, R. (2002). The Rise of the Creative Class and How It's Transforming Work, Leisure, Community and Everyday Life. New York: Basic Books. 
Florida, R. (2005). Cities and the Creative Class. New York: Routledge.

Gill, R., Pratt, A. (2008). In the Social Factory? Immaterial Labour, Precariousness and Cultural Work, Theory, Culture \& Society. King's College London: London, 25 (7-8), 1-30.

Griffin, R.W. (1996). Podstawy zarzadzania organizacjami. Warszawa: Wydawnictwo Naukowe PWN.

Jaworski, J. (2006). Restrukturyzacja polskiego przemysłu zbrojeniowego. Prace Komisji Geografii Przemystu Polskiego Towarzystwa Geograficznego, 9, 130-142.

Kilar, W. (2011). Wpływ kryzysu na funkcjonowanie korporacji Panasonic. Prace Komisji Geografii Przemystu Polskiego Towarzystwa Geograficznego, 17, 187-196.

Kloosterman, R.C. (2010). Building a Career: Labour Practices and Cluster Reproduction in Dutch Audiovisual Industry. Regional Studies, 44 (7), 859-872.

Kocowski, T. (1991). Szkice z teorii twórczości i motywacji. Poznań: SAWW.

Koźmiński, A. K., Piotrowski, W. (red.) (1997). Zarządzanie. Teoria i praktyka. Warszawa: Wydawnictwo Naukowe PWN.

Landry, Ch. (2006). The Creative City. A Toolkit for Urban Innovators. London: Earthscan

Malecki, E.J. (1987). The R\&D Location Decision of the Firm and 'Creative' Regions. Technovation, $6,205-222$.

McRobbie, A. (1998). British Fashion Design; Rag trade or Image Industry? London: Routledge.

McRobbie, A. (2002). The Los Angelisation of London. Three Short-Waves of Young People's Microeconomies of Culture and Creativity in the UK. EIPCP - Evropski Institut za Progresivnu Kulturnu Politiku [Pozyskano: http://eipcp.net/transversal/0207/mcrobbie/en

Nalepka, A., Ujwary-Gil, A. (red.) (2010). Organizacje komercyjne i niekomercyjne wobec wzmożonej konkurencji oraz wzrastających wymagań konsumentów. Nowy Sącz: Wydawnictwo WSB-NLU w Nowym Sączu, 102-115.

Napier, K.N., Nilsson, V. (2006). The Development of Creative Capabilities in and Out of Creative Organizations: Three Case Studies. Creativity and Innovation, 15 (3), 268-278.

Rachwał, T. (2011). Industrial Restructuring in Poland and Other European Union States in the Era of Economic Globalization. Procedia. Social and Behavioral Sciences, 19, 1-10.

Rachwał, T. (2006). Efekty restrukturyzacji wybranych przedsiębiorstw przemysłowych Polski Południowo-Wschodniej. Prace Komisji Geografii Przemystu Polskiego Towarzystwa Geograficznego, 9, 98-115.

Stolarick, K., Florida, R. (2006). Creativity, Connections and Innovation: A Study of Linkages in the Montréal Region. Environment and Planning, A 38 (10), 1799-1817.

Storper, M., Scott, A.J. (2009). Rethinking Human Capital, Creativity and Urban Growth. Journal of Economic Geography, 9 (2), 147-167.

Stryjakiewicz, T. (2004). Sieci gospodarcze w Polsce w warunkach transformacji systemowej. W: J.J. Parysek (red.), Rozwój regionalny i lokalny w Polsce w latach 1989-2002. Poznań: Bogucki Wydawnictwo Naukowe.

Stryjakiewicz, T., Męczyński, M. (2010). Atrakcyjność poznańskiego obszaru metropolitalnego dla pracujacych w sektorze kreatywnym. Poznań: Bogucki Wydawnictwo Naukowe.

Stryjakiewicz, Y., Stachowiak, K. (2010). Sektor kreatywny w poznańskim regionie metropolitalnym. Uwarunkowania, poziom i dynamika rozwoju sektora kreatywnego w poznańskim obszarze metropolitalnym. Poznań: Bogucki Wydawnictwo Naukowe.

Tobolska, A. (2008). Nowy model organizacji i funkcjonowania wybranych przedsiębiorstw przemysłowych. Prace Komisji Geografii Przemystu Polskiego Towarzystwa Geograficznego, 9, 83-97. 
Törnqvist, G. (1983). Creativity and the Renewal of Regional Life. W: A. Buttimer (ed.), Creativity and Context. Lund Studies in Geography, Series B, 50, 91-112.

Törnqvist, G. (2004). Creativity in Time and Space. Geografiska Annaler, 86, 227-243.

Törnqvist, G. (2011). The Geography of Creativity. Cheltenham, UK; Northampton, MA: Edward Elgar Publishing Ltd.

Vang, J. (2007). The Spatial Organization of the News Industry: Questioning Assumptions about Knowledge Externalities for Clustering of Creative Industries. Innovation: Management, Policy \& Practice. eContent Management Pty Ltd., 9, 14-27.

Wiedermann, K. (2008). Czynniki i skutki rozwoju przemysłu motoryzacyjnego na terenie województwa śląskiego. Prace Komisji Geografii Przemysłu Polskiego Towarzystwa Geograficznego, 10, 93-108.

Zioło, Z. (2008). Procesy transformacji przemysłowych układów przestrzennych na tle zmieniającego się otoczenia. Prace Komisji Geografii Przemystu Polskiego Towarzystwa Geograficznego, 10, $11-22$.

\section{Strony internetowe}

Culture.pl (2012). Pozyskano z: www.culture.pl.

Kulczyk Investments (2012). Pozyskano z: www.kulczykinvestments.com.

Nina.gov.pl (2012). Pozyskano z: www.nina.gov.pl.

Stary Browar - Fundacja 5050 (2012). Pozyskano z: www.starybrowar5050.com

Michal Męczyński, dr, Uniwersytet im. Adama Mickiewicza w Poznaniu, Instytut Geografii Społeczno-Ekonomicznej i Gospodarki Przestrzennej.

Michał Męczyński pracuje od 2006 r. jako adiunkt w Instytucie Geografii Społeczno-Ekonomicznej i Gospodarki Przestrzennej Uniwersytetu im. Adama Mickiewicza w Poznaniu. Jako pracownik naukowy uczestniczył w licznych krajowych i międzynarodowych projektach badawczych, m.in. w międzynarodowym projekcie badawczym ACRE - Accommodating Creative Knowledge. Competitiveness of European Metropolitan Regions within the Enlarged Union (Wykorzystanie kreatywnej wiedzy. Konkurencyjność europejskich regionów metropolitalnych w rozszerzonej Unii) finansowanym ze środków 6 Programu Ramowego Unii Europejskiej. Michał Męczyński jest autorem wielu krajowych i międzynarodowych publikacji dotyczących problematyki innowacyjności i kreatywności. Jego zainteresowania badawcze dotyczą w szczególności rozwoju sektora kreatywnego w obszarach metropolitalnych, zachowań przestrzennych przedstawicieli tego sektora oraz zróżnicowania przestrzennego uwarunkowań innowacyjności gospodarki.

Michal Męczyński, PhD, has worked as a Senior Lecturer at the Institute of Socio-Economic Geography and Spatial Management of Adam Mickiewicz University in Poznań since 2006. He has participated in many national and international projects, e.g. ACRE - Accommodating Creative Knowledge. Competitiveness of European Metropolitan Regions within the Enlarged Union financed from the $6^{\text {th }}$ Framework Programme of the European Union. Męczyński is an author and co-author of numerous Polish and international publications related to the innovativeness and creativity. His research interests are related to development of the creative sector in metropolitan regions, spatial behaviors of talented and highly skilled individuals and spatial differences of the innovative economy.

adres/address: Uniwersytet im. Adama Mickiewicza w Poznaniu

Instytut Geografii Społeczno-Ekonomicznej i Gospodarki Przestrzennej

ul. Dzięgielowa 27, 61-680 Poznań, Polska

e-mail: micmec@amu.edu.pl 